УДК 331.101 .1

UDK 331.101 .1

Чеберячко C.I., Дерюгін О.В., Третяк О.О., Муха О.А.

Національний технічний університет «Дніпровська політехніка», м. Дніпро, Украӥна

\title{
ОЦІНКА ЕРГОНОМІЧНИХ РИЗИКІВ ЗДОРОВ’Ю РОБІТНИКІВ АВТОСЕРВІСУ
}

\begin{abstract}
Професійні захворювання опорно-рухового апарату працівників автосервісу $\epsilon$ одними 3 найрозповсюдженіших серед цієї категорії робітників. Саме вони зменшують продуктивність праці та якість життя. Тому пошук шляхів для забезпечення безпеки і комфорту на робочому місці та обгрунтування рішень щодо удосконалення ергономіки технологічного процесу є актуальним завданням.

Мета дослідження - оцінка ергономічних ризиків здоров’ю працівників автосервісу під час здійснення виробничої діяльності, пов'язаної з ремонтом і технічним обслуговуванням автомобілів та обгрунтування способів їх зниження.

Для оцінки ризику виникнення професійних захворювань опорно-рухового апарату скористаємось методом швидкої оцінки робочої пози працівників (Rapid Entire Body Assessment worksheet ("REBA")).

За результатами проведеного дослідження - встановлено, що найбільша ймовірність захворювання опорно-рухового апарату виникає у працівників шиномонтажу. Для цієї технологічної операції є характерною ручна робота 3 великим навантаженням при значній кількості незручних поз. Визначено, що найбільш ризикованими операціями з обслуговування є розкручування (закручування шайок) та установка (знімання) колеса, що пов'язано насамперед 3 поєднанням значного фізичного зусилля і незручної пози. При цьому ймовірність травмування опорно-рухового апарату складає майже - 99\%. Наведено характеристику сучасного обладнання для підвищення безпеки праці за ергономічним критерієм - зменшення фізичного навантаження на робітників. Встановлено, що його використання призведе до покращення рівня безпеки на - $60 \%$.

В результаті проведеного дослідження, було показано на прикладі проведення оцінки ергономічного ризику, що за його величиною можна визначити найбільш травмонебезпечні операції та обгрунтувати доцільність удосконалення технологічного процесу, зокрема шиномонтажу, за рахунок збільшення використання засобів механізації роботи автомеханіка.

Ключові слова: підприємство автосервісу, зміна функціонального стану організму, метод REBA, ризик, ергономіка
\end{abstract}

\section{ВСТУП}

За даними Фонду соціального страхування України, основними причинами виникнення професійних захворювань робітників на промисловому виробництві, $є$ недосконалість механізмів та робочого інструменту - 25,4\%, недосконалість технологічного процесу - 18,4\% та неефективність роботи засобів індивідуального захисту - $15,1 \%$. У структурі професійних захворювань перше місце займають хвороби органів дихання - 39,8\% від загальної кількості діагнозів по Україні (873 випадки). Захворювання опорно-рухового апарату (ЗОРА) (радикулопатії, остеохондрози, артрити, артрози) складають 27,6\% (606 випадків), хвороби слуху - 12\% (263 випадки), вібраційна хвороба - 5,8\% (127 випадків) (рис. 1) [1].

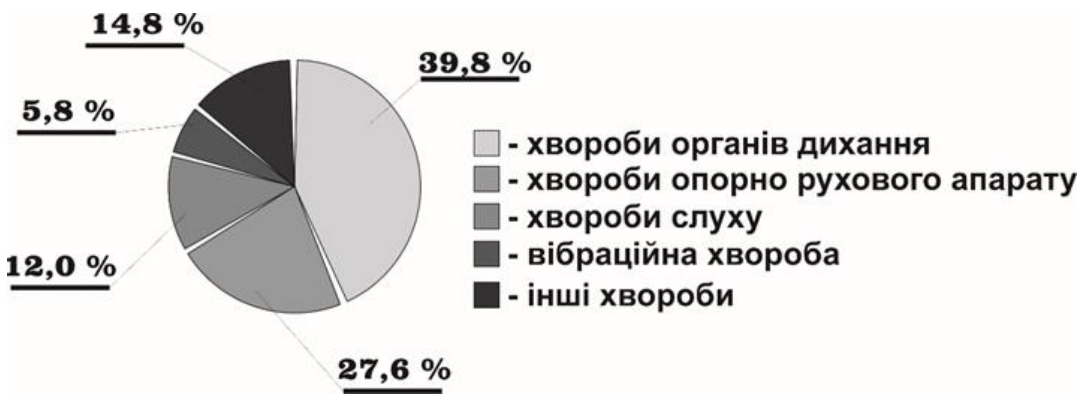

Рисунок 1. Структура професійних захворювань працівників промислових підприємств в Україні

Автомобільний сервіс, в нашій країні, охоплює значний соціальний сегмент працюючих (приблизно 200 тис. осіб), оскільки його послугами користуються кожний автовласник. На жаль, статистичні дані свідчать про зростання кількості нещасних випадків та професійних захворювань у цій галузі (за минулий рік тільки у Дніпропетровській області зафіксовано 120 випадків, що у 2,5 рази більше від попереднього [2]. Робота працівника автосервісу характеризується великою кількістю важкої ручної роботи, наявністю у більшості технологічних операцій з технічного обслуговування 
або ремонту (ТО і Р) потенційних небезпек його здоров'ю, які характеризуються великою кількістю одноманітних стереотипних рухів 3 додаванням значних фізичних зусиль, травмонебезпечними позами тулуба при виконанні технологічної операції, низьким рівнем автоматизації праці, відсутністю у більшості випадків ефективного ергономічного обладнання тощо. Саме тому, оцінка ергономічних ризиків для виявлення потенційних небезпек здоров'ю працівників автосервісу дозволить обгрунтувати способи їх усунення, що $є$ актуальним і важливим завданням.

\section{АНАЛІЗ ЛІТЕРАТУРНИХ ДАНИХ ТА ПОСТАНОВКА ПРОБЛЕМИ}

Ергономіка вивчає взаємозв'язок між умовами і об'єктами роботи для забезпечення високої працездатності і безпеки працівників $[3,4]$. Важливою їі складовою $є$ встановлення вимог до робочих місць, знарядь праці і навколишнього середовища для мінімізації їх впливу на фізичні і психологічні властивості працівників [5]. Звідси виникає необхідність у проведенні всебічних досліджень, які пов'язані з вивченням антропометричних, психофізіологічних, сенсомоторних та енергетичних характеристик людини, для організації, просторового компонування, розмірів, технологічного оснащення, розміщення виробничого обладнання та технологічних ліній. Для вирішення цих завдань виконується велика кількість наукових праць [6-14], які спрямовані перш за все на дослідження умов праці для зменшення імовірності ризику виникнення професійних захворювань опорно-рухового апарату працівника під час виконання виробничої діяльності. Однак аналіз наукових досліджень показав використання складних механізмів щодо визначення критеріїв для покращення комфорту на робочих місцях, які здебільшого трудомісткі і недоступні для використання. Тому виникає потреба саме в простих методах оцінювання ергономічних ризиків, що дозволить обгрунтовувати інженерні рішення з підвищення як рівня безпеки, так і комфорту праці $[10,11]$.

\section{ЦІЛЬ ТА ЗАДАЧІ ДОСЛІДЖЕННЯ}

Об’єкт дослідження - ергономічні ризики при ремонті автомобіля.

Ціль дослідження - оцінка ергономічних ризиків здоров’ю працівників автосервісу під час виконання виробничої діяльності 3 ремонту і технічного обслуговування автомобілів та обгрунтування шляхів їх зниження.

\section{РЕЗУЛЬТАТИ ДОСЛІДЖЕНЬ}

Для оцінки ризику виникнення професійних захворювань опорно-рухового апарату скористаємось методом швидкої оцінки робочої пози працівників - "REBA" (рис. 2). Він представляє собою спеціальний бланк, який розділений на дві частини "А" i "В". До першої належить розташування тулуба, шиї та ніг. Друга частина присвячена оцінці розташування плечей, ліктів та зап'ястя. Виходячи 3 діапазонів та напрямку руху суглобів, величини зусиль, навантаження та стану активності, розраховується відповідний бал для кожної частини тіла, які потім за допомогою спеціальної таблиці дозволяють визначити величину ризику виникнення професійного захворювання опорно-рухового апарату працівника.

Кожний етап розділений на декілька кроків. Перші три присвячені встановленню балів, які відповідають положенню частин тіла: шиї, тулуба, ніг. Кожному положенню частини тіла, яке визначається через аналіз фотографії відповідає певна кількість балів, які потім підставляються у таблицю "А" для визначення результуючого значення. На наступному кроці до отриманого значення додаються бали, які відповідають величині зусилля чи навантаження на працівника при виконанні відповідної роботи. Одержаний результат, дозволяє знайти відповідний стовбець у таблиці "С". Далі переходимо до визначення балів, які відповідають розташуванню передпліччя, плеча і зап'ястя. Встановлені бали підставляють у таблицю "В", що дозволяє отримати результуюче значення. Додаючи до нього бали, які характеризують тип захвату встановлюємо величину, яка допомагає знайти необхідний рядок у таблиці "C". На перетині - знайдемо результуючий показник ризику, для уточнення якого додають бали, що відповідають за активність і складність роботи.

У результаті одержимо певну цифру, інтерпретація, якої дозволить прийняти управлінське рішення, щодо зменшення рівня ризику виникнення захворювання. Загальним результатом проведеної оцінки $є$ величина ризику виникнення захворювання опорно-рухового апарату, який $\epsilon$ високим і потребує кардинальних змін технології виконання робіт. 


\section{REBA Employee Assessment Worksheet}

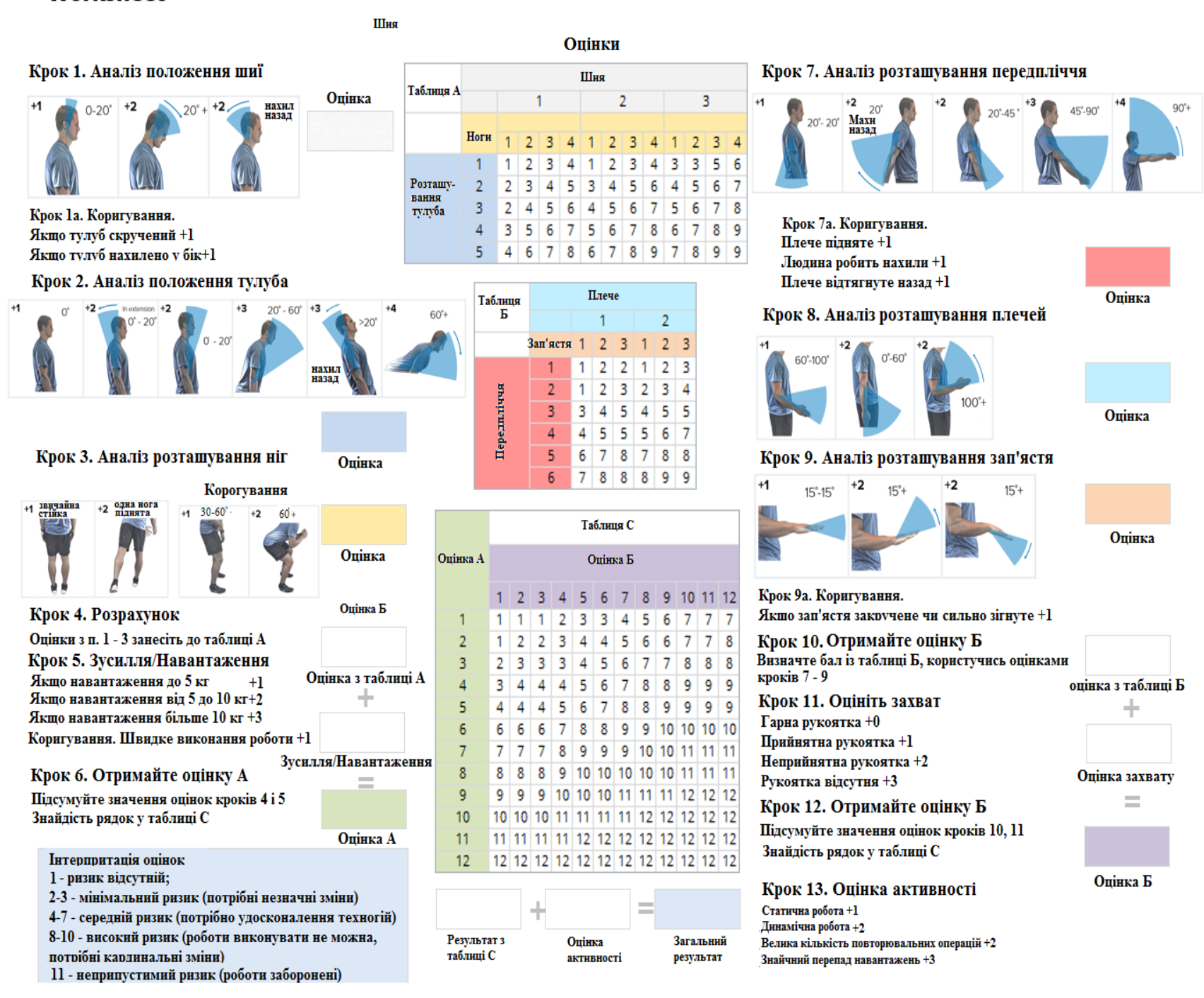

Рисунок 2. Чек-лист для оцінки ергономічного ризику виникнення захворювань опорно-рухового апарату

Загальну величину ергономічного ризику за формулою [15]:

$$
R_{E P}=1-\prod_{i-1}^{n} S_{E P i},
$$

де $S_{E P i}$ - рівень безпеки виконання $i$ - ой технологічної операції з ремонту або обслуговування автомобіля:

$$
S_{E P}=\frac{\left(x_{\max }+1\right)-x_{i}}{x_{\max }},
$$

де $x_{\max }$ - максимальна бальна оцінка, яка визначається за результатами обробки розташування працівників на робочому місці методом "REBA"; $x_{i}$ - бальна оцінка ергономічного ризику, яка визначена за методом "REBA" за відповідною операцією технологічного процесу ремонту або обслуговування автомобіля.

Під час виконання виробничих операцій в незручних позах існує декілька варіантів настання небажаних подій, які пов’язані зі ЗФСО працівника автосервісу (рис. 3). 


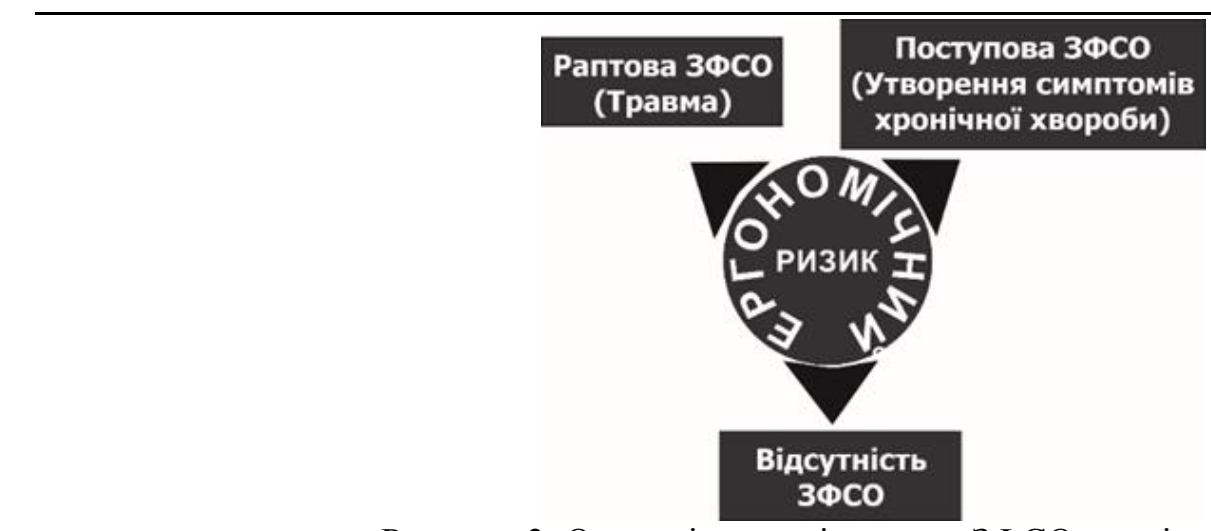

Рисунок 3. Основні сценарії прояву ЗФСО працівника автосервісу

Визначення величини ймовірності настання небезпечної події проведемо на прикладі виконання технологічного процесу - заміна пошкодженого колеса легкового автомобіля. Запропонована технологічна операція $є$ найменш автоматизованою i вимагає від працівників автосервісу знаходитися під час іiї виконання в доволі незручних робочих позах із застосуванням ручної роботи, яка вимагає великих фізичних зусиль при виконанні наступних технологічних операцій: зривання гайок, установку домкрата, зняття/заміна колеса та ін. Величину бальних оцінок ергономічного ризику проводили, виходячи із аналізу фотознімків положення тулуба працівника автосервісу при виконанні відповідної технологічної операції, на яких попередньо була зроблена структурна схема фіксації частин тулуба і кутів між ними. За допомогою чек-листа методу «REBA» встановлено ергономічний ризик за відповідними технологічними операціями. Для прикладу на рис. 4, 5 наведено алгоритм розрахунку величини ергономічного ризику при виконанні технологічної операції - зривання гайок з колеса.

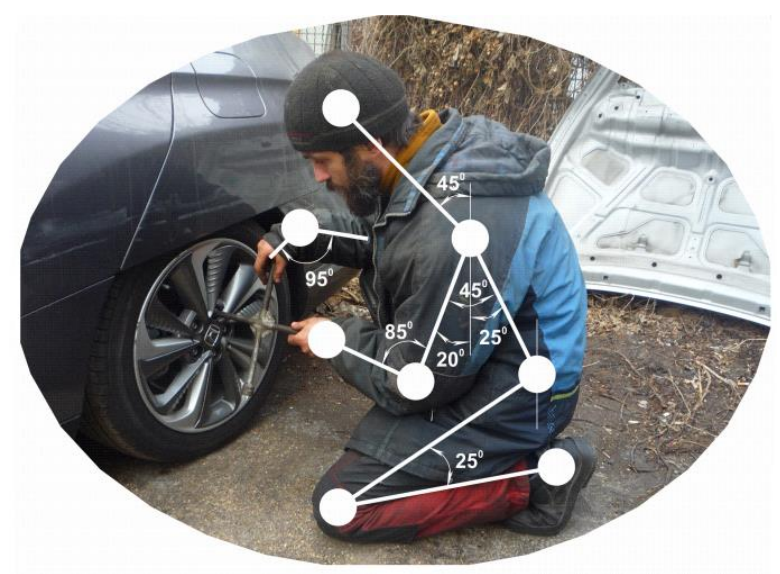

Рисунок 4. Зображення працівника, що виконує технологічну операцію - зривання кріпильних гайок колеса легкового автомобіля з нанесеною структурною схемою положення тулуба

В подальшому за формулами (1) і (2) розраховується імовірність настання професійного захворювання/травмування для кожної технологічної операції (табл. 1). Аналіз отриманих результатів говорить про значну небезпеку ЗФСО працівника автосервісу. Найбільш ризикованими операціями 3 обслуговування $є$ розкручування (закручування шайок) та установка (знімання) колеса, що пов'язано насамперед 3 поєднанням значного фізичного зусилля і незручної пози. При цьому ймовірність травмування/професійного опорно-рухового апарату складає майже 99\%. Зменшення цієї величини можливе лише за рахунок впровадженням хоча б часткової механізації/автоматизації технологічного процесу. Запропоновано нове ергономічне обладнання, яке дозволить зменшити рівень ризику наведене в табл. 2. В результаті подальших обрахунків вже нових поз і зусиль під час виконання шиномонтажу з урахуванням модернізації наведені в табл. 3. Розрахунки показують,, що його використання призведе до покращення рівня безпеки на $60 \%$, при цьому рівень ризику буде середнім. 


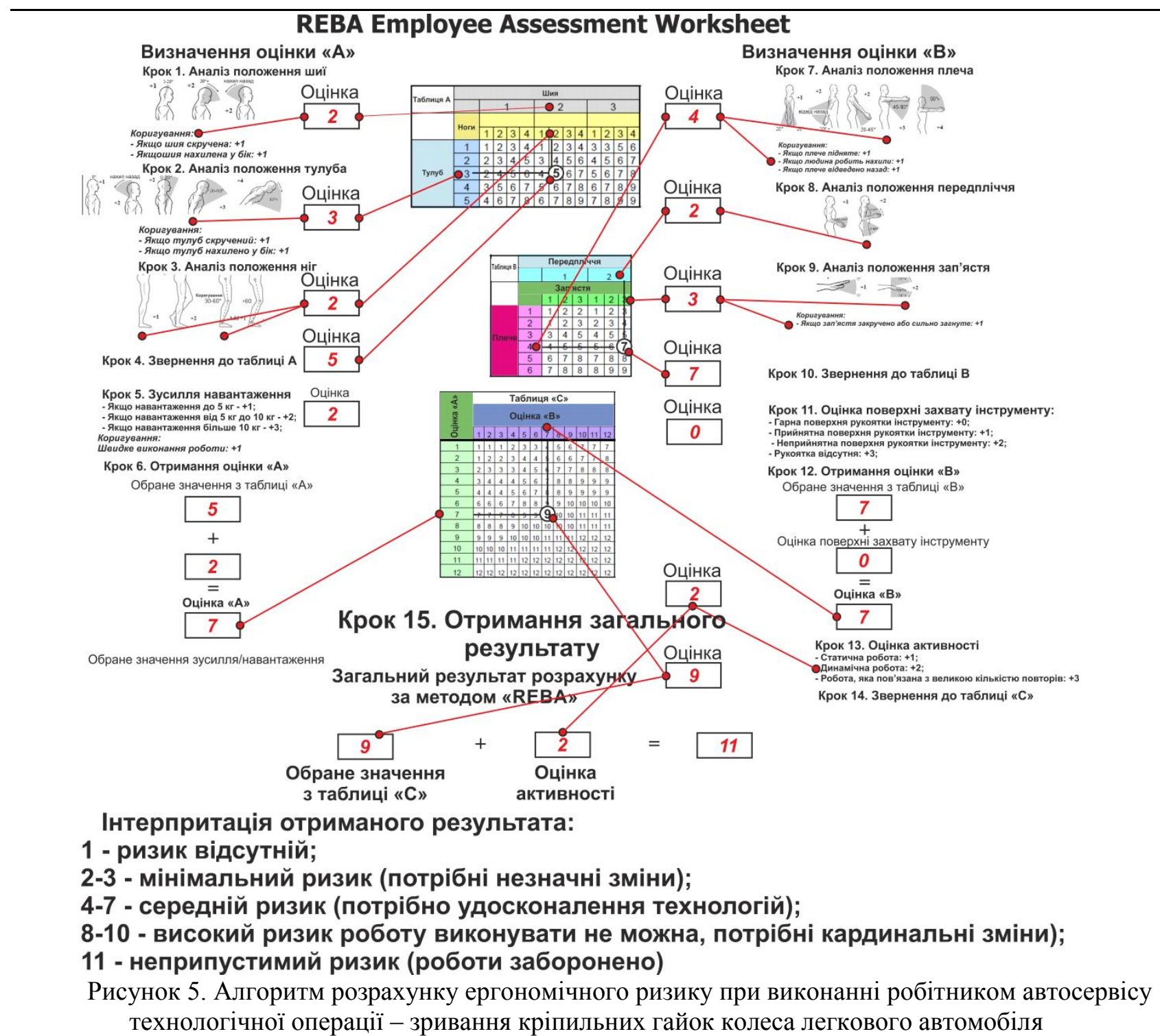

\section{ОБГОВОРЕННЯ РЕЗУЛЬТАТІВ ДОСЛІДЖЕННЯ}

В цілому, результати оцінювання ергономічного ризику дозволяють адекватно обгрунтувати витрати на закупівлю нового ергономічного обладнання. I хоча рівень ризику в результаті запропонованого рішення $є$ середнім, (помірним) - це дозволяє при дотриманні відповідних інструкцій все ж таки зменшити ймовірність травмування чи виникнення професійного захворювання. Однак, це не означає «зупинку», потрібні інші інженерні рішення і подальші дослідження, що, в цілому, дозволяє здійснити запроваджена система управління безпекою праці на основі ризик-орієнтованого підходу. Вона сьогодні широко впроваджується на вітчизняних підприємствах, в тому числі і на підприємствах автосервісу. На думку багатьох фахівців, вона $€$ досить результативною [16-19], що підтверджено реальним станом виробничого травматизму на підприємствах та спонукає до постійного пошуку та виявлення небезпек і ,відповідно, їх усунення. Особливо такий підхід актуальний при обгрунтуванні витрат на усунення небезпеки зі значним рівнем ризику. 3 іншого боку ризикам із незначним рівнем також потрібно приділяти належну увагу, хоча їх величина знаходиться у прийнятній зоні, що не може завдати значної шкоди працівникам, у яких, однак через накопичувальну дію 3 часом 3'являється захворювання. Виходячи 3 розуміння окресленої проблеми все більше небайдужих фахівців намагаються удосконалити та запропонувати альтернативні підходи до систем управління ергономікою і гігієною праці. Тому, запропонований метод, який враховує ергономічні критерії - дозволить не тільки обгрунтувати доцільність закупівлі ефективного обладнання, а й реально сприятиме підвищенню продуктивності праці, що збільшить прибуток автосервісного підприємства, а не лише його витрати на охорону праці. 
( Чеберячко С.I., Дерюгін О.В., Третяк О.О., Муха О.А. 2020

Таблиця 1 Результати розрахунку ймовірності ергономічного ризику працівника автосервісу

\begin{tabular}{|c|c|c|c|c|c|}
\hline $\begin{array}{c}\text { Технологічний } \\
\text { процес }\end{array}$ & $\begin{array}{c}\text { Затягування } \\
\text { гайок }\end{array}$ & $\begin{array}{c}\text { Установка } \\
\text { домкрата і } \\
\text { підйом } \\
\text { автомобіля }\end{array}$ & $\begin{array}{c}\text { Розкручування } \\
\text { (закручування) } \\
\text { гайок }\end{array}$ & $\begin{array}{c}\text { Зняття } \\
\text { (установка)колеса }\end{array}$ & $\begin{array}{l}\text { Заміна } \\
\text { колеса }\end{array}$ \\
\hline \multicolumn{6}{|l|}{$\begin{array}{c}\text { Нова поза при } \\
\text { виконанні } \\
\text { операцій }\end{array}$} \\
\hline $\begin{array}{c}\text { Результат, } \\
\text { отриманий за } \\
\text { методом } \\
\text { "REBA" }\end{array}$ & 11 & 5 & 11 & 11 & 6 \\
\hline Рівень ризику & Неприпустимий & Середній & Неприпустимий & Неприпустимий & Середній \\
\hline $\begin{array}{c}\text { Рівень безпеки } \\
\text { виконання } \\
\text { технологічної } \\
\text { операції } S_{E P}\end{array}$ & 0.083 & 0,583 & 0.083 & 0.083 & 0,583 \\
\hline $\begin{array}{c}\text { Ймовірність } \\
\text { захворювання/ } \\
\text { травмування, } \\
R\end{array}$ & & & 0.99 & & \\
\hline
\end{tabular}

Таблиця 2 Обладнання для удосконалення технологічного процесу заміни пошкодженого колеса легкового автомобіля

\begin{tabular}{|c|c|c|c|c|}
\hline $\begin{array}{l}\text { № } \\
\Pi / \Pi\end{array}$ & Технологічний процес & $\begin{array}{c}\text { Технологічне } \\
\text { обладнання }\end{array}$ & $\begin{array}{c}\text { Вартість } \\
\text { обладнання, } \\
\text { грн./\$ }\end{array}$ & Виробник \\
\hline \multirow{2}{*}{1.} & \multirow{2}{*}{$\begin{array}{c}\text { Зривання } \\
\text { (затягування) гайок }\end{array}$} & $\begin{array}{l}\text { Ножичний } \\
\text { підйомник }\end{array}$ & $150000 / 6200$ & $\begin{array}{c}\text { TOВ «Форстор» 49006, } \\
\text { Дніпро, пр. Пушкіна, буд. } \\
\text { 8a.Email: info@forstor.ua } \\
\end{array}$ \\
\hline & & $\begin{array}{c}\text { Пневматичний } \\
\text { гайковерт }\end{array}$ & $12000 / 500$ & $\begin{array}{c}\text { TOВ «Форсаж», м. Мінськ, вул } \\
\text { Орловська, буд. 40, Білорусь } \\
\text { Email: info@ forsagebel.by }\end{array}$ \\
\hline \multirow[b]{2}{*}{2.} & \multirow{2}{*}{$\begin{array}{c}\text { Установка (зняття) } \\
\text { домкрату і підйом } \\
\text { (опускання) } \\
\text { автомобіля }\end{array}$} & $\begin{array}{l}\text { Ножичний } \\
\text { підйомник }\end{array}$ & $150000 / 6200$ & $\begin{array}{c}\text { TOВ «Форстор» 49006, } \\
\text { Дніпро, пр. Пушкіна, буд. 8а. } \\
\text { Email: info@ forstor.ua }\end{array}$ \\
\hline & & $\begin{array}{c}\text { Пневматичний } \\
\text { домкрат }\end{array}$ & $4000 / 160$ & $\begin{array}{c}\text { TOВ «Індастріал-Сервіс» } \\
\text { 49000, Дніпро, вул. Стартова, } \\
\text { буд. 20. Email: } \\
\text { kiev@indservice.com.ua } \\
\end{array}$ \\
\hline 3. & Закручування гайок & $\begin{array}{c}\text { Пневматичний } \\
\text { гайковерт }\end{array}$ & $12000 / 500$ & $\begin{array}{l}\text { ТОВ «Форсаж», м. Мінськ, } \\
\text { вул. Орловська, буд. 40, } \\
\text { Білорусь Email: } \\
\text { info@ forsagebel.by }\end{array}$ \\
\hline 4. & $\begin{array}{c}\text { Зняття } \\
\text { (установка)колеса }\end{array}$ & \multirow{2}{*}{$\begin{array}{c}\text { Візок для зняття і } \\
\text { транспортування } \\
\text { автомобільних коліс }\end{array}$} & \multirow[t]{2}{*}{$35000 / 1430$} & \multirow{2}{*}{$\begin{array}{c}\text { TOВ «Форсаж», м. Мінськ, вул } \\
\text { Орловська, буд. 40, Білорусь } \\
\text { Email: info@forsagebel.by }\end{array}$} \\
\hline 5. & Заміна колеса & & & \\
\hline
\end{tabular}


Таблиця 3 Результати розрахунку ймовірності ергономічного ризику ЗФСО працівника автосервісу при виконанні технологічного процесу - заміна пошкодженого колеса легкового автомобіля після запровадженні заходів з використанні ергономічного обладнання

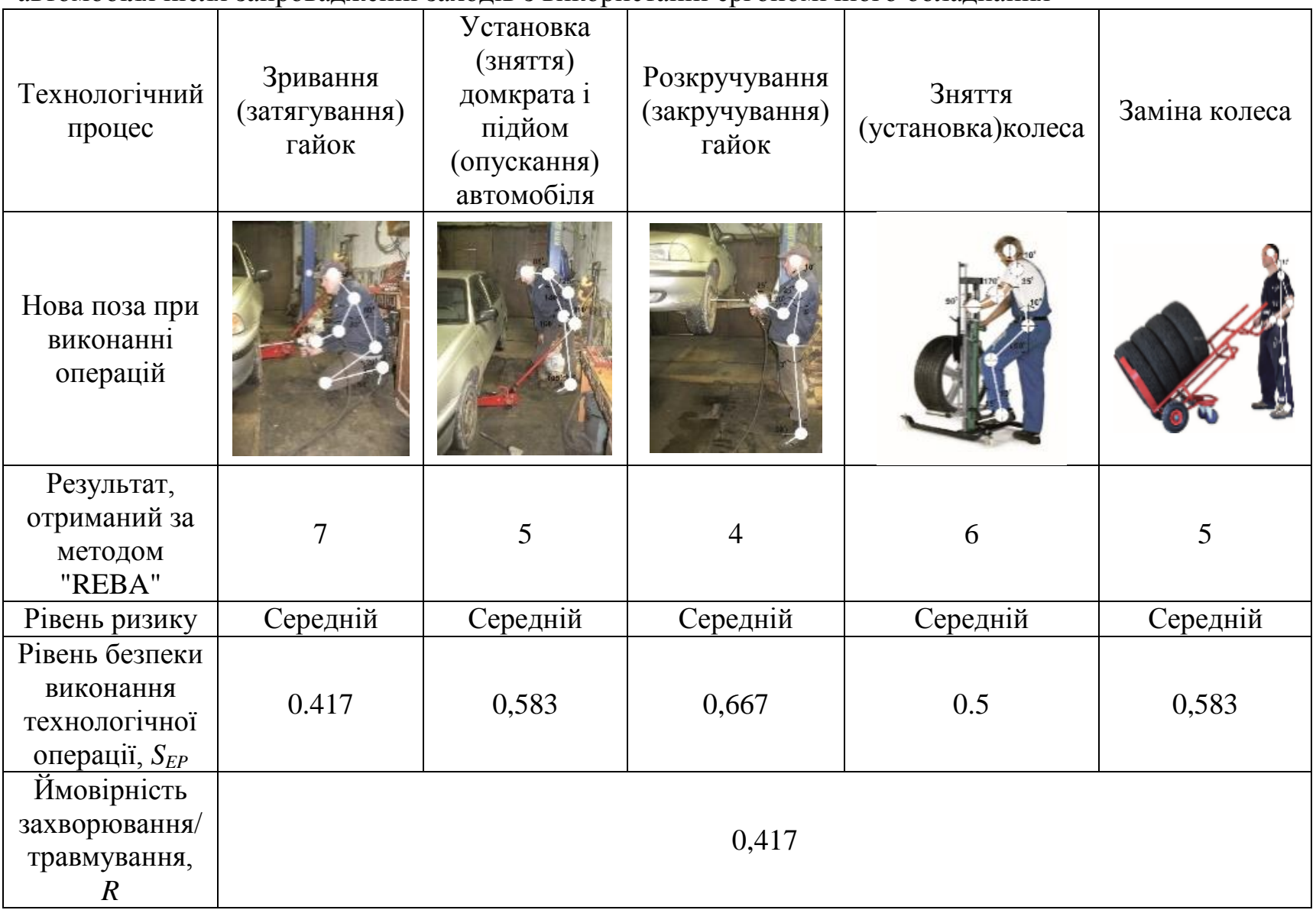

\section{ВИСНОВКИ}

Проведена оцінка ергономічних ризиків при шиномонтажних роботах за допомогою методу "REBA". Встановлено, що найбільша ймовірність захворювання опорно-рухового апарату на автосервісі у працівників шиномонтажу, для якого характерна ручна робота зі значним навантаженням при значній кількості незручних поз. Визначено, що найбільш ризикованими операціями з обслуговування є розкручування (закручування шайок) та установка (знімання) колеса, що пов'язано насамперед 3 поєднанням фізичних зусиль і незручної пози. При цьому ймовірність травмування опорно-рухового апарату складає майже - 99\%. Наведено характеристику сучасного обладнання для підвищення безпеки праці за ергономічним критерієм - зменшення фізичних витрат робітників. Встановлено, що його використання призведе до покращення рівня безпеки на - $60 \%$.

В результаті проведеного дослідження на конкретних прикладах було показано проведення оцінювання ергономічного ризику, за величиною якого можна визначити найбільш травмонебезпечні операції та обгрунтувати доцільність удосконалення технологічного процесу, зокрема шиномонтажу, за рахунок збільшення використання засобів механізації роботи автомеханіка.

\section{ПЕРЕЛІК ДЖЕРЕЛ ПОСИЛАННЯ}

1. Державна служба статистики України. Травматизм на виробництві в Україні у 2017 році. Статистичний збірник. Київ - 2018 рік, 132 с.

2. Дайджест новин фонду соціального страхування України з 10 по 15 грудня 2018 року. // Фонд соціального страхування України: Режим доступу: http:// http://www.fssu.gov.ua/fse/control/chnig/uk/publish/article/101426 (дата звернення: 15.05.2020).

3. Al Madani, D., \& Dababneh, A. (2016). Rapid Entire Body Assessment: A Literature Review. American Journal of Engineering and Applied Sciences, 9(1), 107-118. DOI: 10.3844/ajeassp.2016.107.118. 
4. Subramanian, S., Raju, N., Srinivasan, P., Jeganathan, K., \& Jayaraman, S. (2018). Low back pain assessment using surface electromyography among industry workers during the repetitive bending tasks. International Journal of Human Factors and Ergonomics, 5(4), 277-292. DOI: 10.1504/IJHFE.2018.096112.

5. Workplace injuries and illnesses - 2011. // Bureau of Labor Statistics. Workplace injuries and illnesses - 2011. Режим доступу: http://www.bls.gov/news.release/archives/osh 10252012.pdf. - Загол. 3 екрану. (дата звернення: 15.05.2020).

6. Bejan, A., Brosseau, L.M., \& Parker, D.L. (2011). Exposure assessment in auto collision repair shops. Journal of Occupational and Environmental Hygiene, 8, 401-408. DOI: 10.1080/15459624.2011.585117.

7. Dembe, A.E., Erickson, J.B., Delbos, R.G., \& Banks, S.M. (2005). The impact of overtime and long work hours on occupational injuries and illnesses: new evidence from the United States. Occupational Environment Medicine, 62, 588-597. DOI: 10.1136/oem.2004.016667.

8. Sorock, G.S, Lombardi, D.A., Hauser, R., Eisen, E.A., Herrick, R.F., \& Mittleman, M.A. (2004). A case-crossover study of transient risk factors for occupational acute hand injury. Occupational Environment Medicine, 61(4), 305-311. DOI: 10.1136/oem.2002.004028.

9. Dotson, G.S. (2006). Characterization of asbestos exposure among automotive mechanics servicing and handling asbestos-containing materials. Graduate Theses and Dissertations. http://scholarcommons.usf.edu/etd/2506.

10. Mukhopadhyay, P., \& Khan, A. (2015). The Evaluation of Ergonomic Risk Factors Among Meat Cutters Working In Jabalpur, India. International Journal of Occupational and Environmental Health, 21(3), 192-198. DOI: 10.1179/2049396714y.0000000064.

11. Sukapto, P., Cynthia, F., \& Standiklaus, S. (2019). Application of the REBA method to osh systems to increase work productivity (a case study at pt. eksonindo mpi, Bandung, Indonesia). International Journal of Civil Engineering and Technology, 10(3), 3088-3098. Article ID: IJCIET_10_03_311.

12. Motamedzade, M., Mohammad, R.A., Rostam, G., \& Hossein, M. (2011). Comparison of Ergonomic Risk Assessment Outputs from Rapid Entire Body Assessment and Quick Exposure Check in an Engine Oil Company. Journal Of Research In Health Sciences, 1(1), 26-32. DOI: 10.18869/acadpub.johe.2.4.195.

13. Ansari, N.A., \& Sheikh, M.J. (2014). Evaluation of work Posture by RULA and REBA: A Case Study. IOSR Journal of Mechanical and Civil Engineering, 11(4), 18-23. DOI: 10.9790/1684-11431823.

14. Moradi, M., Poursadeghiyan, M., Khammar, A., Hami, M., Darsanj, A., \& Yarmohammadi, H. (2017). REBA method for the ergonomic risk assessment of auto mechanics postural stress caused by working conditions in Kermanshah (Iran). Annals of Tropical Medicine and Public Health, 10(3), 589-594. DOI: 10.4103/ATMPH.ATMPH_107_17.

15. Минько В.М. Математическое моделирование в охране труда. Монография / В.М. Минько. Калининград: Изд-во ФГБОУ ВПО «КГТУ», 2007. - 200 с.

16. Stradina, G., Ievins, J., Roja, Z., Kalkis, V., \& Kalkis, H. (2014). Ergonomic Risks in the Printing Company and Workers' Wellbeing. Safety of Technogenic Environment, 5, 43-46. DOI: 10.7250/ste.2014.005.

17. Roja, Z., Kalkis, H., Reinholds, I., \& Cekuls, A. (2016). Ergonomics risk analysis in construction operations. Agronomy Research, 14(1), 211-219. Retrieved from http:// https://agronomy.emu.ee/wpcontent/uploads/2016/05/Vol14-_nr1_Roja.pdf\#abstract-4105.

18. Jan, D., \& Neumann, W.P. (2009). Ergonomics Contributions to Company Strategies. Applied Ergonomics, 40(4), 745-752. DOI:10.1016/j.apergo.2008.07.001.

19. Lamond, D., Daniels, K., \& Standen, P. (2003). Teleworking and Virtual Organisations: The Human Impact. Chapter 11 (p. 213-234) in the book: The New Workplace: A Guide to the Human Impact of Modern Working Practices. UK: John Wiley \& Sons, 464 p. ISBN: 978-0-471-48543-8.

\section{REFERENCES}

1. State Statistics Service of Ukraine. (2018). Injuries at work in Ukraine in 2017, [Travmatyzm na vyrobnytstvi v Ukrayini u 2017 rotsi]. Statistical collection. Kyiv, 132 p. [In Ukraine].

2. "News digest of the Social Insurance Fund of Ukraine from December 10 to 15, 2018", [Daydzhest novyn fondu sotsial'noho strakhuvannya Ukrayiny z 10 po 15 hrudnya 2018 roku]. - 2018 [Internet]. Website Social Insurance Fund of Ukraine. Retrieved from: URL: http://www.fssu.gov.ua/fse/control/main/uk/index. [In Ukraine]. 
3. Al Madani, D., \& Dababneh, A. (2016). Rapid Entire Body Assessment: A Literature Review. American Journal of Engineering and Applied Sciences, 9(1), 107-118. DOI: 10.3844/ajeassp.2016.107.118.

4. Subramanian, S., Raju, N., Srinivasan, P., Jeganathan, K., \& Jayaraman, S. (2018). Low back pain assessment using surface electromyography among industry workers during the repetitive bending tasks. International Journal of Human Factors and Ergonomics, 5(4), 277-292. DOI: 10.1504/IJHFE.2018.096112.

5. Workplace injuries and illnesses - 2011. // Bureau of Labor Statistics. Workplace injuries and illnesses - 2011 [Internet]. Retrieved from: http://www.bls.gov/news.release/archives/osh_10252012.pdf.

6. Bejan, A., Brosseau, L.M., \& Parker, D.L. (2011). Exposure assessment in auto collision repair shops. Journal of Occupational and Environmental Hygiene, 8, 401-408. DOI: 10.1080/15459624.2011.585117.

7. Dembe, A.E., Erickson, J.B., Delbos, R.G., \& Banks, S.M. (2005). The impact of overtime and long work hours on occupational injuries and illnesses: new evidence from the United States. Occupational Environment Medicine, 62, 588-597. DOI: 10.1136/oem.2004.016667.

8. Sorock, G.S, Lombardi, D.A., Hauser, R., Eisen, E.A., Herrick, R.F., \& Mittleman, M.A. (2004). A case-crossover study of transient risk factors for occupational acute hand injury. Occupational Environment Medicine, 61(4), 305-311. DOI: 10.1136/oem.2002.004028.

9. Dotson, G.S. (2006). Characterization of asbestos exposure among automotive mechanics servicing and handling asbestos-containing materials. Graduate Theses and Dissertations. http://scholarcommons.usf.edu/etd/2506.

10. Mukhopadhyay, P., \& Khan, A. (2015). The Evaluation of Ergonomic Risk Factors Among Meat Cutters Working In Jabalpur, India. International Journal of Occupational and Environmental Health, 21(3), 192-198. DOI: 10.1179/2049396714y.0000000064.

11. Sukapto, P., Cynthia, F., \& Standiklaus, S. (2019). Application of the REBA method to osh systems to increase work productivity (a case study at pt. eksonindo mpi, Bandung, Indonesia). International Journal of Civil Engineering and Technology, 10(3), 3088-3098. Article ID: IJCIET_10_03_311.

12. Motamedzade, M., Mohammad, R.A., Rostam, G., \& Hossein, M. (2011). Comparison of Ergonomic Risk Assessment Outputs from Rapid Entire Body Assessment and Quick Exposure Check in an Engine Oil Company. Journal Of Research In Health Sciences, 1(1), 26-32. DOI: 10.18869/acadpub.johe.2.4.195.

13. Ansari, N.A., \& Sheikh, M.J. (2014). Evaluation of work Posture by RULA and REBA: A Case Study. IOSR Journal of Mechanical and Civil Engineering, 11(4), 18-23. DOI: 10.9790/1684-11431823.

14. Moradi, M., Poursadeghiyan, M., Khammar, A., Hami, M., Darsanj, A., \& Yarmohammadi, H. (2017). REBA method for the ergonomic risk assessment of auto mechanics postural stress caused by working conditions in Kermanshah (Iran). Annals of Tropical Medicine and Public Health, 10(3), 589-594. DOI: 10.4103/ATMPH.ATMPH_107_17.

15. Min'ko V.M. (2007). Mathematical modeling in labor protection, [Matematicheskoye modelirovaniye v okhrane truda]. Monograph. Kaliningrad: Publish. Kaliningrad State Technical University, 200 p. [In Russian].

16. Stradina, G., Ievins, J., Roja, Z., Kalkis, V., \& Kalkis, H. (2014). Ergonomic Risks in the Printing Company and Workers' Wellbeing. Safety of Technogenic Environment, 5, 43-46. DOI: 10.7250/ste.2014.005.

17. Roja, Z., Kalkis, H., Reinholds, I., \& Cekuls, A. (2016). Ergonomics risk analysis in construction operations. Agronomy Research, 14(1), 211-219. Retrieved from http:// https://agronomy.emu.ee/wpcontent/uploads/2016/05/Vol14-_nr1_Roja.pdf\#abstract-4105.

18. Jan, D., \& Neumann, W.P. (2009). Ergonomics Contributions to Company Strategies. Applied Ergonomics, 40(4), 745-752. DOI: 10.1016/j.apergo.2008.07.001.

19. Lamond, D., Daniels, K., \& Standen, P. (2003). Teleworking and Virtual Organisations: The Human Impact. Chapter 11 (p. 213-234) in the book: The New Workplace: A Guide to the Human Impact of Modern Working Practices. UK: John Wiley \& Sons, 464 p. ISBN: 978-0-471-48543-8.

\section{S. Cheberyachko, O. Deryugin, O. Tretyak, O. Mukha. Evaluating ergonomic health risks to car service employees.}

Occupational diseases of the musculoskeletal system in car service employees are among the most wide spread ones as for the labour grade. The diseases reduce productivity, and decrease life quality. Thus, search for ways to provide occupational safety and comfort as well as to substantiate decisions concerning the improved ergonomics of operational procedures is the topical problem. 
Aim of the research is to evaluate ergonomic health risks to car service employees in the process of their production activities intended to repair and maintain cars, and to substantiate ways of their decrease.

Apply "REBA" (Rapid Entire Body Assessment) worksheet to evaluate risks of occupational diseases of the musculoskeletal system.

The research has helped determine that rim servicing personnel is the category of employees who are the most exposed to the musculoskeletal system diseases. The matter is that intensive muscular works in the context of inconvenient body positioning are typical for the operation. It has been identified that untightening/tightening the screws and wheel mounting/dismounting are the most risky procedures being first connected with a significant physical effort-inconvenient body positioning combination. In this context, potential injury of the musculoskeletal system is almost $99 \%$. The current equipment to improve labour safety has been characterized in terms of ergonomic criterion i.e., reducing the physical load on employees. It has been identified that the equipment use will improve the safety level by $60 \%$.

The results of the research, carried out in terms of ergonomic risk evaluation, have demonstrated that the value can identify the most hazardous activity types, and substantiate the expediency to improve operational procedures (among other things, it concerns car tyre fitting) while increasing the number of mechanical equipment to facilitate a car mechanic activities.

Keywords: car service, changes in a functional state of body systems, "REBA" worksheet, risk, ergonomics

ЧЕБЕРЯЧКО Сергій Іванович, доктор технічних наук, професор, кафедра охорони праці та цивільної безпеки, Національний технічний університет «Дніпровська політехніка», Дніпро, Україна, e-mail: sicheb@ukr.net; orcid.org/0000-0003-3281-7157.

ДЕРЮГІН Олег Валентинович, кандидат технічних наук, доцент, кафедра управління на транспорті, Національний технічний університет «Дніпровська політехніка», Дніпро, Україна, e-mail: oleg.kot@ meta.ua; orcid.org/0000-0002-2456-7664.

ТРЕТЯК Олена Олександрівна, кандидат технічних наук, доцент, кафедра управління на транспорті, Національний технічний університет «Дніпровська політехніка», Дніпро, Україна, e-mail: elena.novikova.ut@ukr.net; orcid.org/0000-0002-7542-9392.

МУХА Олег Анатолійович, кандидат технічних наук, доцент, кафедра охорони праці та цивільної безпеки, Національний технічний університет «Дніпровська політехніка», Дніпро, Україна, e-mail: mukha.o.a@nmu.one; orcid.org/0000-0002-1311-8708.

Serhii CHEBERIACHKO, Doctor of Technical Science, Professor, Department of Labour Protection and Civil Safety, Dnipro University of Technology, Dnipro, Ukraine, e-mail: sicheb@ukr.net; orcid.org/0000-0003-3281-7157.

Oleg DERYUGIN, Candidate of Technical Sciences (Ph.D), associate professor, Department of Transportation Management, Dnipro University of Technology, Dnipro, Ukraine, e-mail: oleg.kot@ @meta.ua; orcid.org/0000-0002-2456-7664.

Olena TRETYAK, Candidate of Technical Sciences (Ph.D), associate professor, Department of Transportation Management, Dnipro University of Technology, Dnipro, Ukraine, e-mail: elena.novikova.ut@ukr.net; orcid.org/ 0000-0002-7542-9392.

Oleg MUKHA, Candidate of Technical Sciences (Ph.D), associate professor, Department of Labour Protection and Civil Safety, Dnipro University of Technology, Dnipro, Ukraine, e-mail: mukha.o.a@nmu.one; orcid.org/0000-0002-1311-8708.

DOI 10.36910/automash.v2i15.403 